\title{
Occurrence, abundance and distribution of plant-parasitic nematodes associated with rice (Oryza spp.) in different rice agroecosystems in Togo
}

\author{
Atama GNAMKOULAMBA ${ }^{1,2,3}$, Agbéko Kodjo TOUNOU ${ }^{3 *}$, Atti TCHABI ${ }^{3,4}$, \\ Yao Adjiguita KOLOMBIA ${ }^{5}$, Komi AGBOKA ${ }^{3}$, Manguilibè TCHAO ${ }^{3}$, \\ Anani Kossi Mawuko ADJEVI ${ }^{3}$ and Komla BATAWILA ${ }^{1}$
}

\author{
${ }^{1}$ Faculté des Sciences, Université de Lomé, Laboratoire de Botanique et d'Ecologie Végétale \\ ${ }^{2}$ Institut National de Formation Agricole (INFA) Tové, Ministère de l'Agriculture d'Elevage et de l'Hydraulique \\ ${ }^{3}$ Ecole Supérieure d'Agronomie, Université de Lomé, Laboratoire de Recherche sur les Agroressources et la \\ Santé Environnementale \\ ${ }^{4}$ Université de Kara, Institut des Métier Agricoles \\ ${ }^{5}$ International Institute of Tropical Agriculture (IITA), PMB 5320, Oyo Road, Ibadan, Nigeria. \\ *Corresponding author; Email: ktounou@gmail.com/ktounou@univ-lome.tg, ESA/UL, 01 BP 1515 Lomé 1, \\ Togo, Tel: (228) 90317011
}

\begin{abstract}
Rice is the second most important cereal in Togo. Among constraints that affect rice production, plant parasitic nematodes are of great importance. The objective of this study was to determine the distribution, abundance and frequency of plant nematodes in different agroecological zones of Togo. A total of 50 composite soil and root samples (25 each) were taken from 25 fields (5 per zone) randomly selected from the five agroecological zones. Nematodes were extracted from $100 \mathrm{ml}$ soil and $1 \mathrm{~g}$ fresh root samples using the Hermann techniques. Nematodes were then fixed and mounted on slide and identified to genus level using identification keys. The survey documented twelve plant-parasitic nematode genera among which ten, (Hirschmanniella spp., Meloidogyne spp., Xiphinema spp., Scutellonema spp., Helicotylenchus spp., Heterodera spp., Criconema spp., Pratylenchus spp., Trichodorus spp. and Tylenchid spp.), were recorded from lowland, two (Helicotylenchus and Scutellonema) from upland and five (Dolichodorus spp., Helicotylenchus spp., Tylenchorhynchus spp., Scutellonema spp. and Xiphinema spp.), from flooded ecosystem. Hirschmanniella spp., Meloidogyne spp and Helicotylenchus spp. were the most frequent and abundant plant-parasitic nematode genera recorded from more than $71 \%$ of the samples. Helicotylenchus spp., Hirschmanniella spp., Meloidogyne spp. and Scutellonema spp., were recorded in both soil and root samples while Pratylenchus spp., Heterodera spp. and Tylenchorhynchus spp., were found to be associated to root and Trichodorus spp., Tylenchid spp., Xiphinema spp., Criconema spp. and Dolichodorus spp., were recorded from soil samples only. The high diversity of nematode genera recorded in the survey is attributed to the rice ecosystem, which is mostly characterized by lowland ecosystem with intensive cropping. This study established the evidence that nematodes could be important constraints for rice production, suggesting further research focusing on their damage potential and development of effective rice nematode management strategy for sustainable rice production in Togo.
\end{abstract}

(C) 2018 International Formulae Group. All rights reserved.

Keywords: plant parasitic nematode, abundance, occurrence, rice ecosystem, distribution. 


\section{INTRODUCTION}

A major challenge facing agricultural scientists today is the need to secure food for an increasing world population which is projected to $35 \%$ increase by 2050 (World Bank, 2008). Increasing population suggests an increase in food demand which is estimated to be of about $75 \%$ due to economic development and changes in food preferences (Keating et al., 2010). Among crops that play an importance role in world food security for human being, rice (Oryza sp.) occupies an important place. Grown in about 110 countries around the world, rice is the second most important grain crop after wheat for more than $75 \%$ of world population (Ju-Kon and Krishnan, 2002; Correa et al., 2007). Despite this increase in both rice production and consumption, subSaharan Africa and particularly West Africa, remains the largest importer of rice (Mendez del Villar and Bauer, 2013).

In Togo, rice ranks third among cereals grown after maize and sorghum. The country has enormous human and agroecological potential for rice production. The country has large alluvial plains with rice production potential of about 86,000 ha and lowland areas of more than 185,000 ha. In spite of the enormous rice production potentialities available in Togo, this country continues to import huge quantities of rice to cover national production gap. National rice needs were estimated at 90,000 tons per year for a population of about 7 million inhabitants (DSID, 2003). In order to satisfy an average of $15 \mathrm{~kg}$ of rice per inhabitant per year, Togo has to import 100,000t/year of rice. According to the Agricultural Statistics Department (DSID, 2016), despite an increase of $53.26 \%$ in cultivated rice areas from 1999 to 2015 , paddy rice production in Togo is expected to decline by $4.7 \%$ in the $2015 / 16$ (October/September) season. Among factors that limit rice production worldwide, plant-parasitic nematodes are often cited as one of the most damaging pests (Bridge et al., 2005). Over 4100 species of plant-parasitic nematodes described to date (Decraemer and Hunt, 2006) are known to represent an important constraint on the delivery of global food security. They pose a significant threat to crop production in Africa due to extensive damage and substantial yield losses they cause to a wide range of agricultural crops (Bridge et al., 2005). Moreover, nematode attack can lead to plants' infection by other pathogens (De Waele and Elsen, 2007) either through mechanical damage or on a genetic basis. The direct and indirect damage caused by various plant parasitic nematode species results in delayed crop maturity, toppling, reduced yields and quality of crop product, high production costs and consequently income loss (Sikora and Fernández, 2005; Onkendi et al., 2014). Global damage caused by plant nematodes has been estimated to \$US 80 billion per year (Nicol et al., 2011; Navia et al., 2017).

Although over 4,100 species of plantparasitic nematodes that can be endo- or ectoparasites depending on their lifestyle and attack all the organs of a plant, have been identified (Decraemer and Hunt, 2006), new species are continually being described while others, previously viewed as secondary or nondamaging, are becoming pests as cropping patterns change (Nicol, 2002). Moreover, the distribution of nematode species varies greatly. Some are cosmopolitan, such as Meloidogyne spp. while others (Heterodera spp.) are restricted geographically or are highly host specific.

Among the nematode species known to be associated with rice (Decraemer and Hunt, 2006), only 29 species were reported to be responsible for significant yield losses (Bridge et al., 2005). Despite the daily use and consumption of rice by millions of people in Togo, and its growing importance as a cereal crop, very little is known about the associated plant-parasitic nematodes. Preliminary surveys targeting plant-parasitic nematodes in Togo revealed the presence of Pratylenchus, Meloidogyne, Scutellonema, Heterodera and Hirschmanniella in different rice growing ecologies (De Waele and Elsen, 2007). Although a few surveys of rice nematodes have been conducted in Togo, changes in land use, intensification of agricultural production, and the 
introduction of new varieties could contribute to shifts in the occurrence and density of nematode species or emerging nematode species under different rice agro-ecosystems. Hence, the objective of this study was to analyze the frequency of the occurrence, distribution, and plant-parasitic nematode population densities associated with rice in different agroecological zones of Togo.

\section{MATERIALS AND METHODS}

\section{Study site}

Soil and root samples were collected for nematode analysis from 25 rice fields in the five different agroecological zones of Togo, here referred to as Zone 1, Zone 2, Zone 3 , Zone 4 and Zone 5 (Figure 1) during the 2015 growing season (from September to December 2015). The survey site is characterized by savannah and mountain forest and gallery forest (Kokou et al., 2006). The vegetation is dominated by Combretaceae in the northern plains (Zone 1), Isoberlinia spp Caesalpiniacea in the northern mountains (Zone 2) (Dourma et al., 2012). In the central plains (Zone 3), Anogeisus leiocarpa (Combretaceae) and Pterocarpus erinaceus (Fabaceae) are the most representative (Adjonou et al., 2010) vegetation. The flora is more diversified with Celtis mildbreadii Eng (Cannabaceae), Terminalia superba Eng \& Diels (Combretaceae), Ricinodendron heudelotii (Baill.) (Euphorbiacea) in the southern mountains (Zone 4) while in the southern plains (Zone 5) the mangrove is particularly developed (Adjonou et al., 2010).

\section{Nematode sampling}

Nematode communities and population densities were assessed from 25 fields (5 per ecological zone) according to Hermann (2006). In each field, rice plants and soil were sampled from five points selected along the diagonals. Twenty plants were uprooted at 30 $\mathrm{cm}$ deep using machete from each of the four corners, but avoiding the edges, and at the intercept of the two diagonals. Samples from each field were mixed to form a total of 25 composite soil and root samples. All samples collected were kept in freezer and brought to the "Laboratoire de Recherche sur les Agroressources et la Santé Environnementale" of Université de Lomé-Togo. The samples were processed for extraction within $24 \mathrm{~h}$ after collection and further identification of extracted nematodes. In each sampled field, rice cropping system was recorded while fields were georeferenced using GPS.

\section{Extraction and identification of nematodes}

Each soil sample was thoroughly mixed, and a subsample of $100 \mathrm{ml}$ soil was assayed for nematodes using the Whitehead tray technique (Hooper et al., 2005). For the root samples, a subsample of $10 \mathrm{~g}$ roots were washed, chopped into 1 to $2 \mathrm{~cm}$ pieces and ground for 1 to 2 minutes using a blender (Orisajo and Fademi, 2012) and nematodes were extracted using the above mentioned technique. Nematodes were recovered after an incubation period of $48 \mathrm{~h}$ and identified to genus level in a count plate under a binocular microscope. To confirm the observation with a magnifying binocular microscope and refine the identification a post-lethal observation of individuals killed by heat was carried out. Nematodes were fixed in $4 \%$ formalin, processed in glycerol, and mounted on a glass slide based on a standard procedure (Coyne et al., 2007). Observations were done under the microscope (Motic, Model B1) at X4, X10, $\mathrm{X} 40$ and X100 following the identification keys (Siddiqi, 2000). Three subsamples with equal volume $(10 \mathrm{ml})$ were counted three times, and the average was used to estimate the nematode population prevalence and densities. Prevalence computed as frequency and mean nematode density of the recorded genera in each zone were calculated according to Tayllor and Loegering methods as modified by Araya (2002):

Prevalence: [(number of field positive for genus)/(total number of fields in zone)] $\mathrm{x}$ 100

Mean density in root or soil: [(total number per g root or $100 \mathrm{ml}$ soil)/number of fields positive for genus)]. 


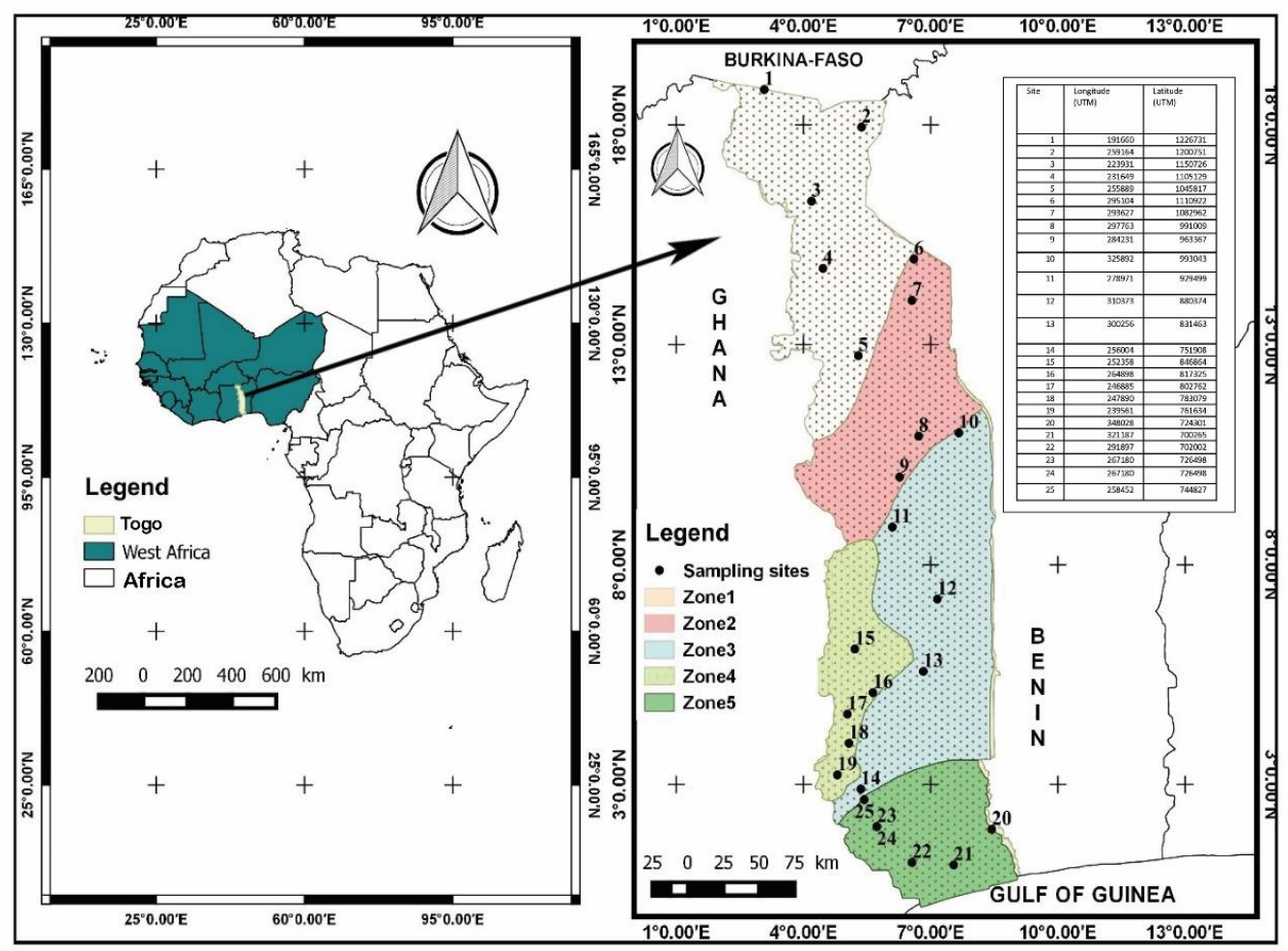

Figure 1: Sample collection sites.

\section{RESULTS}

\section{Diagnostic survey}

A total of 12 nematode genera (Criconema, Dolichodorus, Helicotylenchus, Heterodera, Hirschmanniella, Meloidogyne, Pratylenchus, Scutellonema, Tylenchorhynchus, Trichodorus, Tylenchid and Xiphinema) were found to be associated to rice cultivation in this survey. The Figure 2 showed the morphology of the main genera of nematodes recorded in the present survey.

The prevalence of most genera was low, ranging from 20 to $80 \%$ (Table 1). Hirschmanniella $(80 \%$ in zone 3$)$ and Xiphinema ( $80 \%$ in zone 2) were the most prevalent followed by Meloidogyne (60\% in zone 2 and zone 3) and Scutellonema (60\% in zone 3). Plant parasitic nematode density varied with agroecological zones and nematode habitat, with higher densities recorded from soil samples compared to rice root (Table 1). Some nematodes such as
Meloidogyne and Pratylenchus occurred on rice at population densities as high as 194 and 120 per g root, respectively. Similarly, Hirschmanniella occurred at population density as high as 495 per $100 \mathrm{ml}$ soil and 80 per $g$ root.

The genus Scutellonema occurred in all five agroecological zones of the country, with the species $S$. bradys occurring in Zone 2, while Tylenchorhynchus, Trichodorus, Heterodera, Pratylenchus and Dolichodorus, seem to be agroecologically restricted. Meloidogyne and Hirschmanniella were the most diversified occurring in four of the five agroecological zones, while Xiphinema occurred in three zones (Table 2).

With regard to nematode habitat, five out of twelve genera, Criconema, Dolichodorus, Trichodorus, Tylenchid and Xiphinema, were recorded from soil samples only, while three, Heterodera, Pratylenchus and Tylenchorhynchus were found to be 
associated only to rice roots. The remaining four genera, Helicotylenchus, Hirschmanniella, Meloidogyne and Scutellonema were recorded from both soil and root samples (Figure 3 and Table 2). From the 3,880 individual uncounted, 2,230 individuals $(57.47 \%)$ and 1,650 individuals $(42.53 \%)$, were recorded from soil and root samples, respectively (Figure 3 ). Out of the 50 composite soil samples, the prevalent nematodes encountered were Hirschmanniella, Helicotylenchus, Xiphinema, and Scutellonema with 29.12, 9.54, 6.96, and $5.1 \%$ frequency of occurrence, respectively (Figure 3). Meloidogyne followed by Hirschmanniella with respectively 25.52 and $5.15 \%$ of the recorded nematodes, were the most prevalent genera from the 25 collected root samples (Figure 3).

When comparing rice ecosystem, the highest plant-parasitic nematode population diversity and density were recorded from lowland rice ecosystem, with 1,910 individuals (85.65\%) per $100 \mathrm{ml}$ soil and 1,490 individuals $(90.30 \%)$ per $\mathrm{g}$ of fresh root weight. With ten out of twelve genera (Hirschmanniella (1290 individuals), Meloidogyne (1010 individuals), Xiphinema (240 individuals), Scutellonema (230 individuals), Helicotylenchus (160 individuals), Heterodera (160 individuals), Criconema (130 individuals), Pratylenchus (120 individuals), Trichodorus (40 individuals) and Tylenchid (20 individuals)), the lowland ecosystem shows more nematode diversity than the upland and flooded ecosystems considered together. The latter two rice ecosystems accounting for two (Helicotylenchus and Scutellonema) and five (Dolichodorus, Helicotylenchus, Tylenchorhynchus, Scutellonema and Xiphinema) genera, respectively (Figures 4 and 5).

Total nematode densities of 170 individuals per $100 \mathrm{ml}$ soil and 80 individuals per $g$ root, were counted from flooded rice ecosystem, while 150 individuals per $100 \mathrm{ml}$ soil and 80 individuals per $1 \mathrm{~g}$ were registered from upland rice ecosystem (Figures 4 and 5).
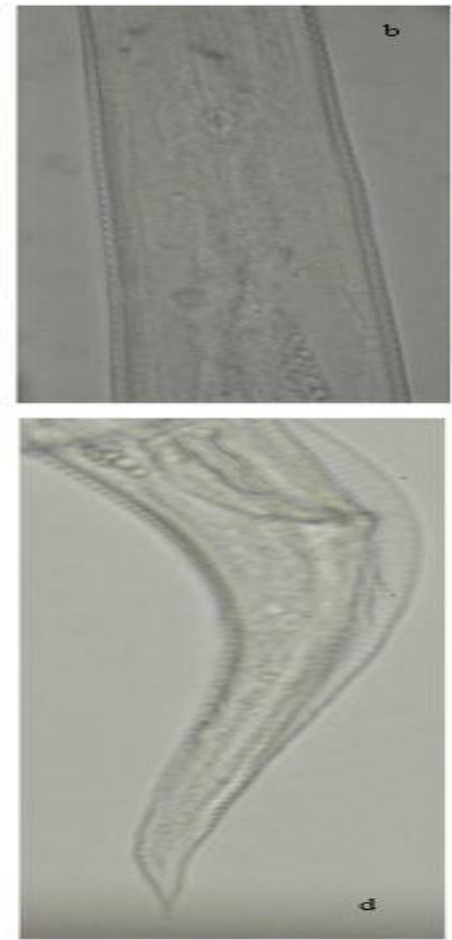

[A] 
A. GNAMKOULABA et al. / Int. J. Biol. Chem. Sci. 12(2): 618-635, 2018

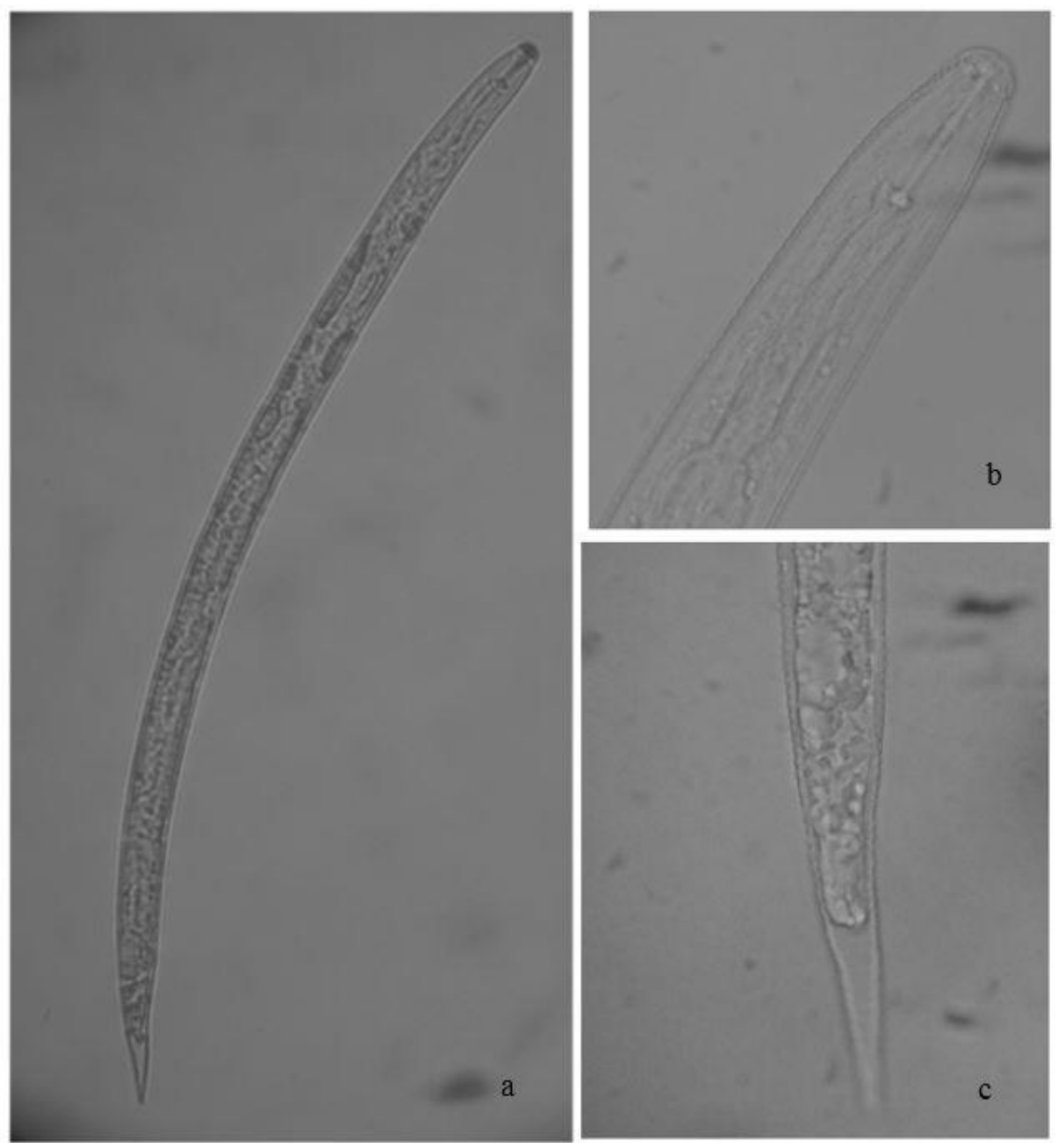

[B]
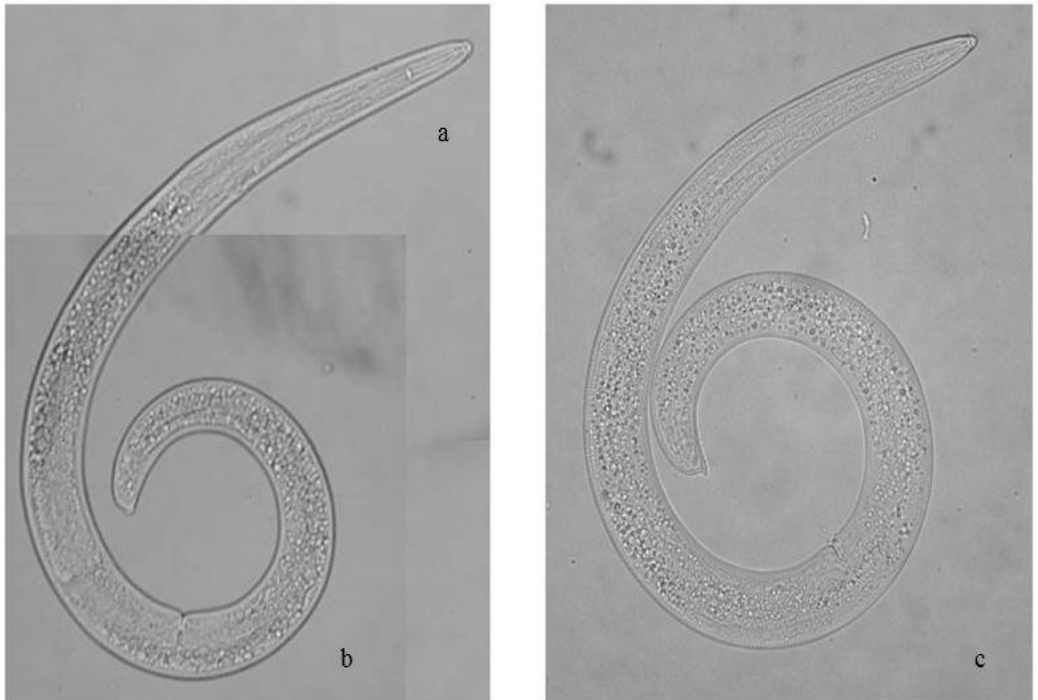

$[\mathrm{C}]$ 
A. GNAMKOULABA et al. / Int. J. Biol. Chem. Sci. 12(2): 618-635, 2018

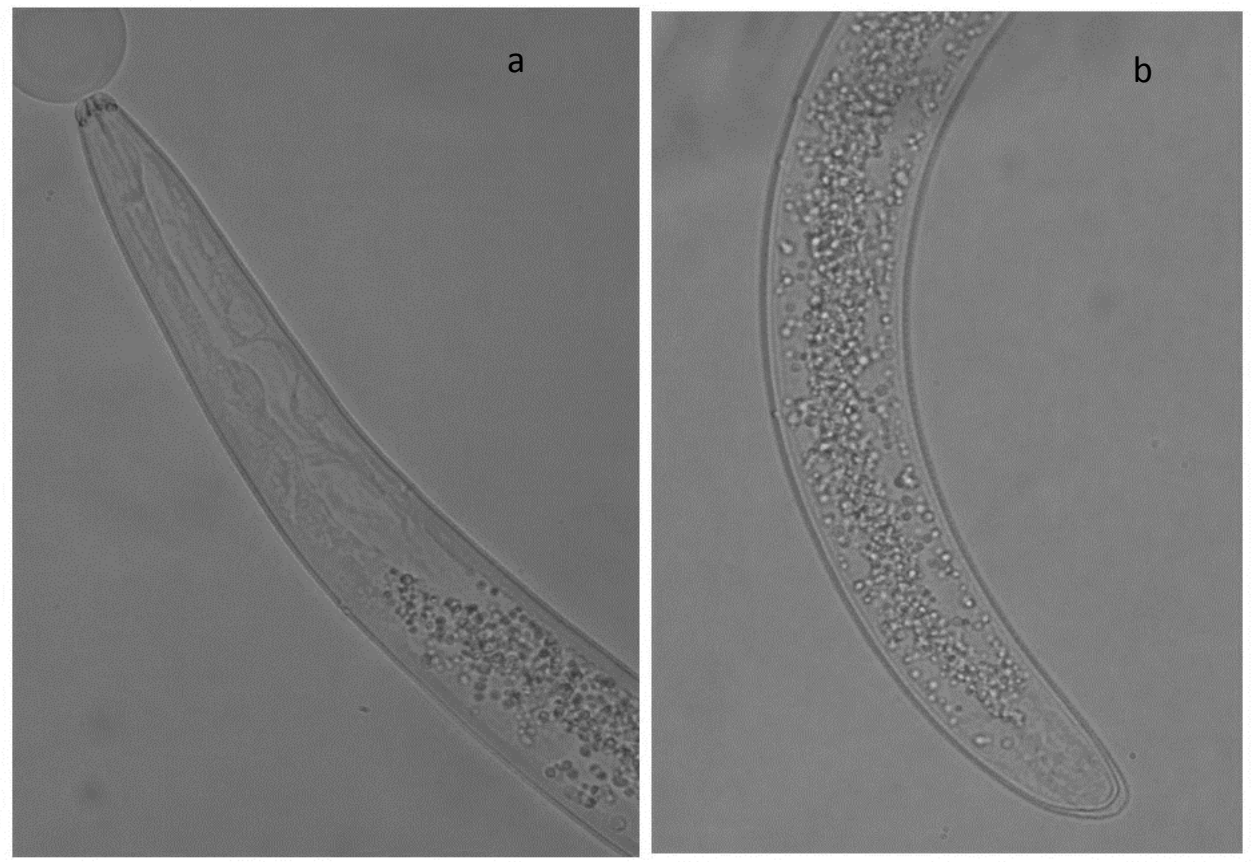

[D]
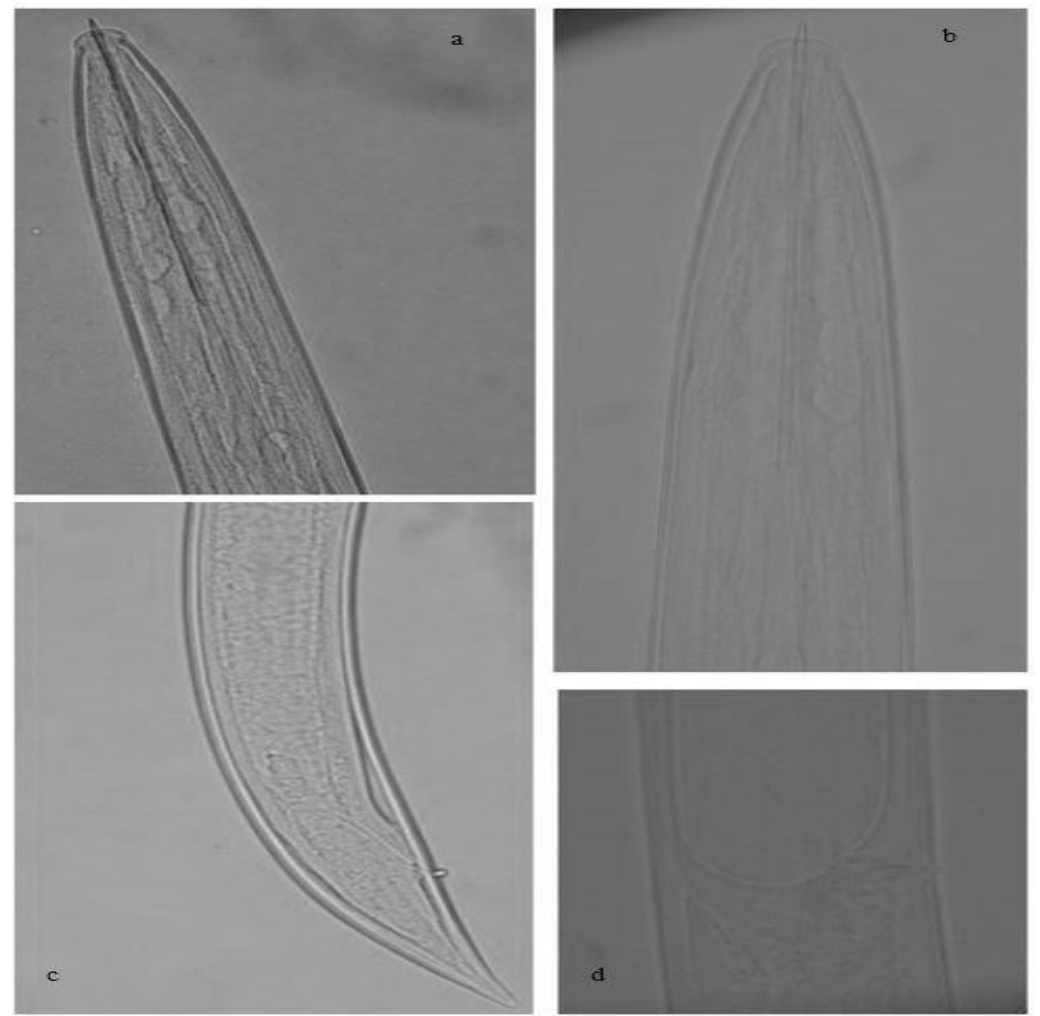

[E] 
A. GNAMKOULABA et al. / Int. J. Biol. Chem. Sci. 12(2): 618-635, 2018
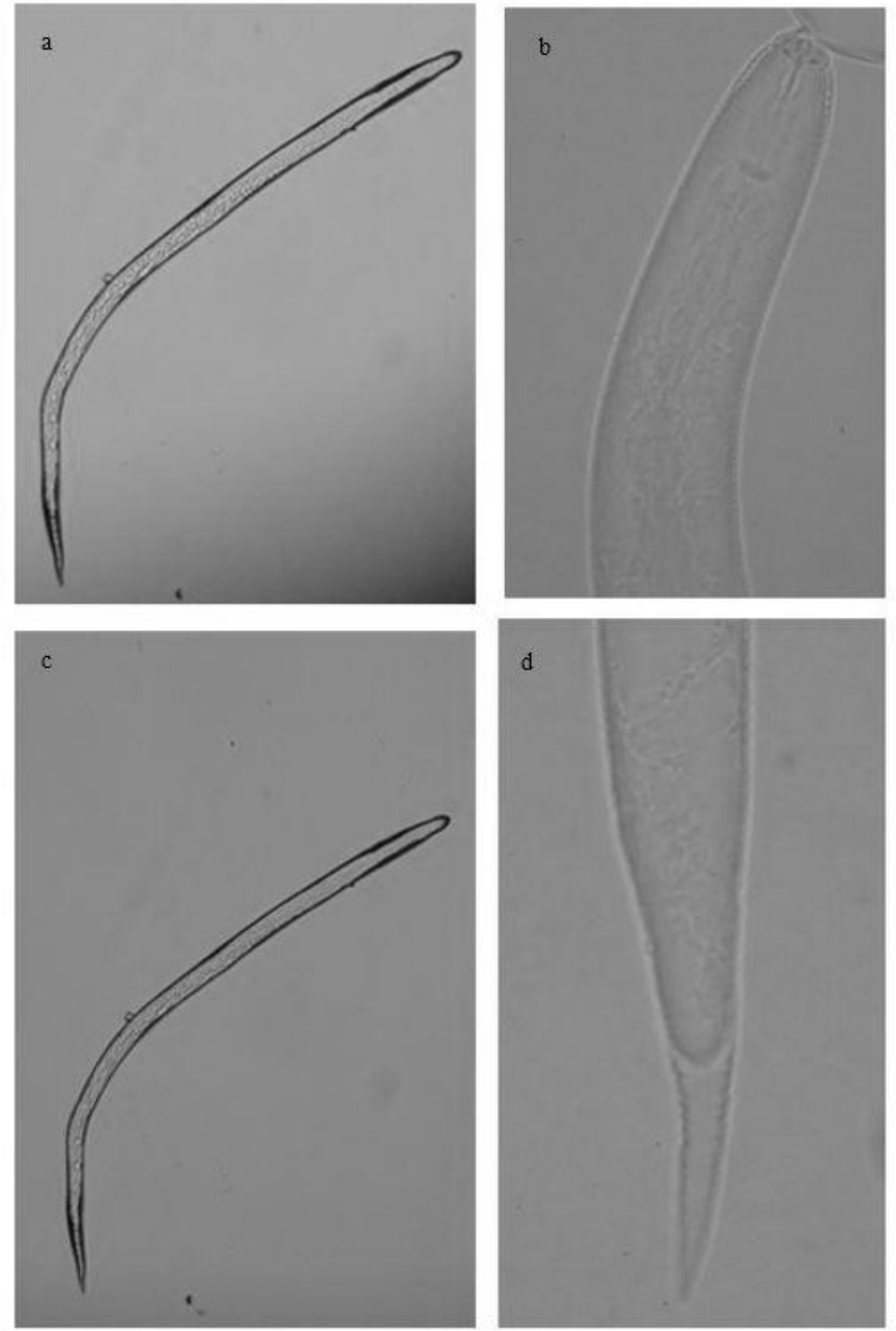

[F] 


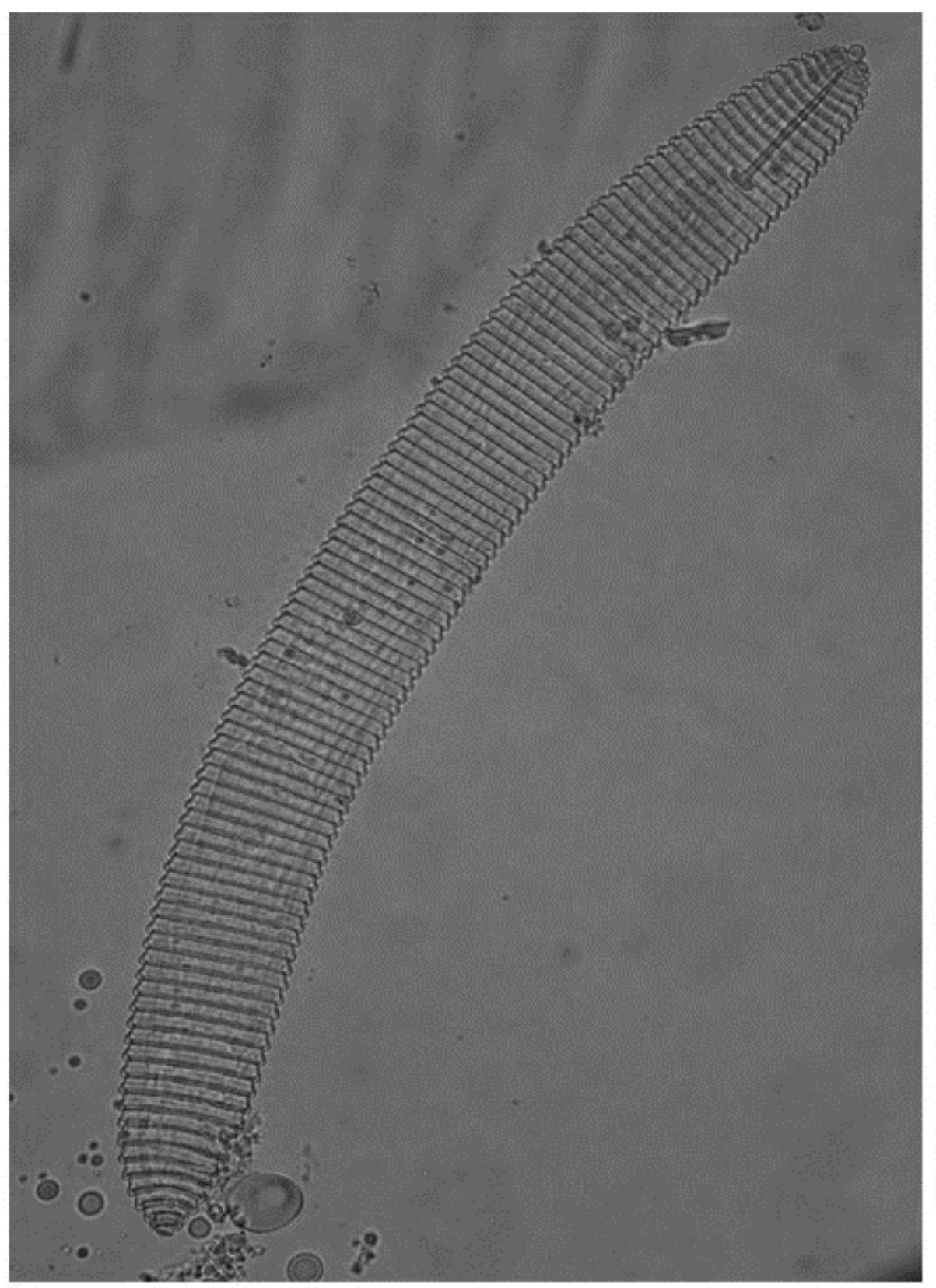

[G]

Figure 2: Morphology of the main plant-parasitic nematode genera recovered from the rice growing ecosystem in Togo: [A] Hirschmanniella spp.: Anterior region of the body (a), pharynx end (b), Posterior region of the female (c) and posterior region of the male (d); [B] Meloidogyne spp.: Entire body (a), anterior region of the body (b), posterior region of the body (c); [C] Helicotylenchus spp.: Anterior region of the body (a), posterior region of the body (b), entire body (c); [D] Scutellonema spp.: Anterior region of the body (a), posterior region of the body (b); [E] Xiphinema spp.: Anterior region of the body (a and b), posterior region of the body (c), base du pharynx (d); [F] Heterodera spp.: Entire body (a and c), anterior region of the body (b), posterior region of the body (d) and [G] Criconema spp.: entire body. 
A. GNAMKOULABA et al. / Int. J. Biol. Chem. Sci. 12(2): 618-635, 2018

Table 1: Prevalence and mean density of plant parasitic nematodes in rice in different agroecological zones of Togo.

\begin{tabular}{|c|c|c|c|c|c|c|c|c|c|c|c|c|c|c|c|}
\hline \multirow{2}{*}{ Nematode genera } & \multirow[b]{2}{*}{$\mathrm{P}(\%)$} & \multicolumn{2}{|c|}{ Zone 1} & \multirow[b]{2}{*}{$\mathrm{P}(\%)$} & \multicolumn{2}{|c|}{ Zone 2} & \multirow[b]{2}{*}{$\mathrm{P}(\%)$} & \multicolumn{2}{|l|}{ Zone 3} & \multirow[b]{2}{*}{$\mathrm{P}(\%)$} & \multicolumn{2}{|l|}{ Zone 4} & \multirow[b]{2}{*}{$\mathrm{P}(\%)$} & \multicolumn{2}{|l|}{ Zone 5} \\
\hline & & Root* & Soil* & & Root & Soil & & Root & Soil & & Root & Soil & & Root & Soil \\
\hline Criconema & - & - & - & 20 & - & 40 & - & - & - & 20 & - & 60 & 20 & - & 30 \\
\hline Dolichodorus & 20 & - & 40 & - & - & & - & - & - & - & - & - & - & - & - \\
\hline Helicotylenchus & - & - & - & 40 & - & 110 & - & - & - & 40 & 40 & 150 & - & - & - \\
\hline Heterodera & - & - & - & - & - & - & - & - & - & & - & - & 20 & 80 & - \\
\hline Hirschmanniella & 40 & 40 & 30 & 20 & - & 80 & 80 & 80 & 495 & 20 & - & 30 & & & - \\
\hline Meloidogyne & - & - & - & 60 & 80 & 20 & 60 & 194 & - & 40 & 105 & - & 20 & 40 & - \\
\hline Pratylenchus & - & - & - & & - & - & - & - & - & 20 & 120 & - & - & - & - \\
\hline Scutellonema bradys & - & - & - & 20 & - & 20 & - & - & - & - & - & - & - & - & - \\
\hline Scutellonema & 40 & - & 60 & & - & - & 60 & 30 & 30 & 20 & 40 & - & 20 & - & 40 \\
\hline Trichodorus & - & - & - & 20 & - & 40 & & - & - & - & - & - & - & - & \\
\hline Tylenchid & - & - & - & - & - & - & & - & - & - & - & - & 20 & - & 20 \\
\hline Tylenchorhynchus & 20 & 40 & & - & - & - & & - & - & - & - & - & & - & \\
\hline Xiphinema & - & - & - & 80 & - & 110 & 40 & - & 30 & - & - & - & 20 & - & 20 \\
\hline
\end{tabular}


A. GNAMKOULABA et al. / Int. J. Biol. Chem. Sci. 12(2): 618-635, 2018

Table 2: Occurrence of plant parasitic nematode genera in soil and root samples from 25 fields of the 5 agroecological zones of Togo during the 2016 growing season.

\begin{tabular}{|c|c|c|c|c|c|c|c|c|c|c|}
\hline \multicolumn{11}{|c|}{ Agroecological Zones $^{a}$} \\
\hline \multirow[t]{2}{*}{ Nématode genera } & \multicolumn{2}{|c|}{ Zone 1} & \multicolumn{2}{|c|}{ Zone 2} & \multicolumn{2}{|c|}{ Zone 3} & \multicolumn{2}{|c|}{ Zone 4} & \multicolumn{2}{|c|}{ Zone 5} \\
\hline & Soil & Root & Soil & Root & Soil & Root & Soil & Root & Soil & Root \\
\hline Criconema & - & - & $*$ & - & - & - & $*$ & - & $*$ & - \\
\hline Dolichodorus & * & - & - & - & - & - & - & - & - & - \\
\hline Helicotylenchus & - & - & & $* *$ & - & - & $* *$ & $* *$ & - & - \\
\hline Heterodera & - & - & - & - & - & - & - & - & - & * \\
\hline Hirschmanniella & $* *$ & $* *$ & * & - & $* *$ & $* *$ & $*$ & - & - & - \\
\hline Meloidogyne & - & - & $* *$ & $* *$ & - & $* *$ & - & $* *$ & - & $*$ \\
\hline Pratylenchus & - & - & - & - & - & - & - & $*$ & - & - \\
\hline Scutellonema & $* *$ & - & * & - & $* *$ & $* *$ & - & $*$ & $* *$ & - \\
\hline Tylenchorhynchus & * & $*$ & - & - & - & - & - & - & - & - \\
\hline Trichodorus & - & - & * & - & - & - & - & - & - & - \\
\hline Tylenchid & - & - & - & - & - & - & - & - & $*$ & - \\
\hline Xiphinema & - & - & $* *$ & - & $* *$ & - & - & - & $*$ & - \\
\hline
\end{tabular}

Legend: (-): not observed; (*): frequency between 0 and 30; (**): frequency between 30 and $80 ;{ }^{a}$ composite samples were collected from growing rice plots. 


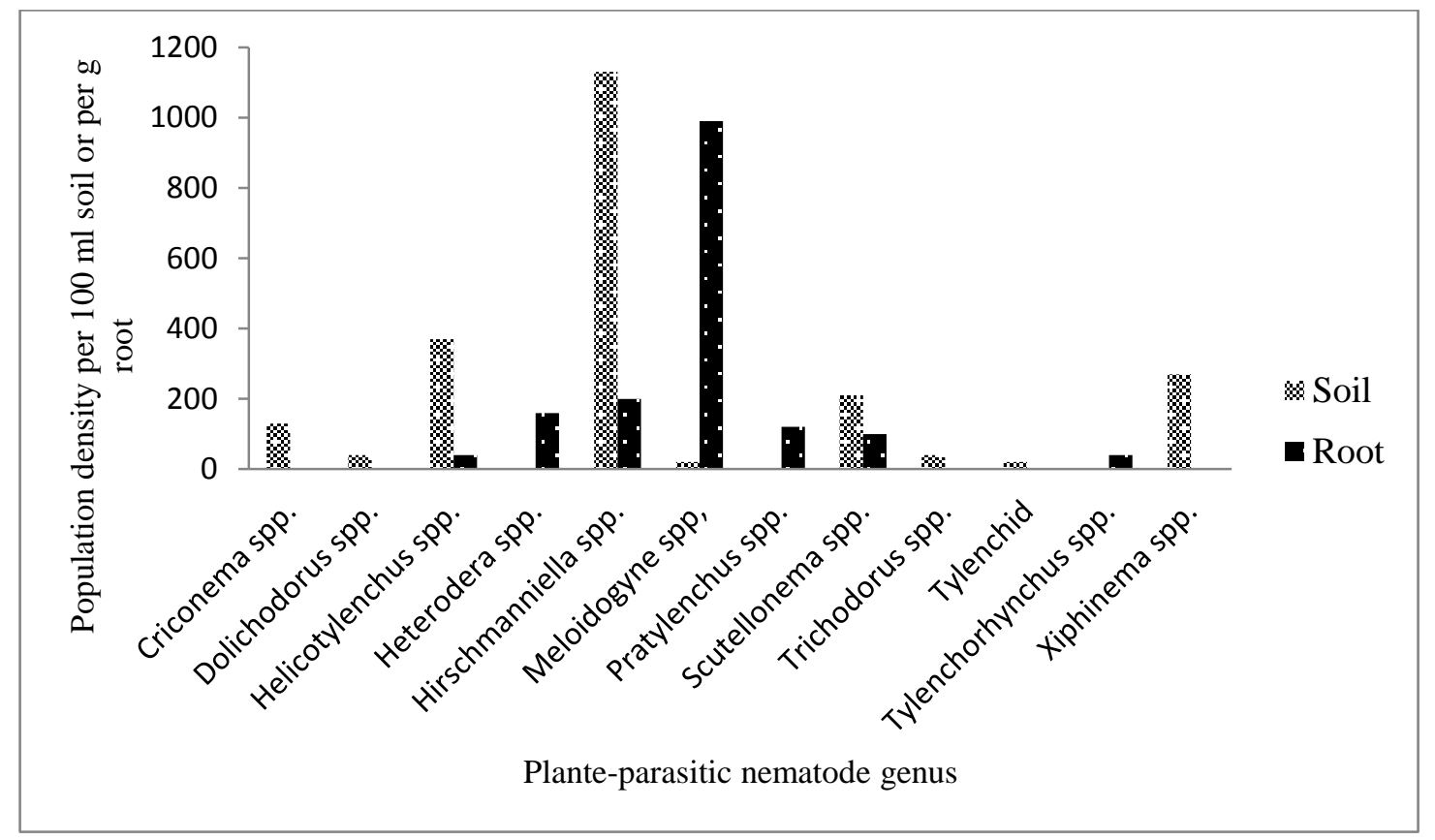

Figure 3: The plant parasitic nematode population density per $100 \mathrm{ml}$ soil sample and per $\mathrm{g}$ fresh root weigh recovered in all the 5 rice agroecological growing zones in Togo, during the 2015 growing season.

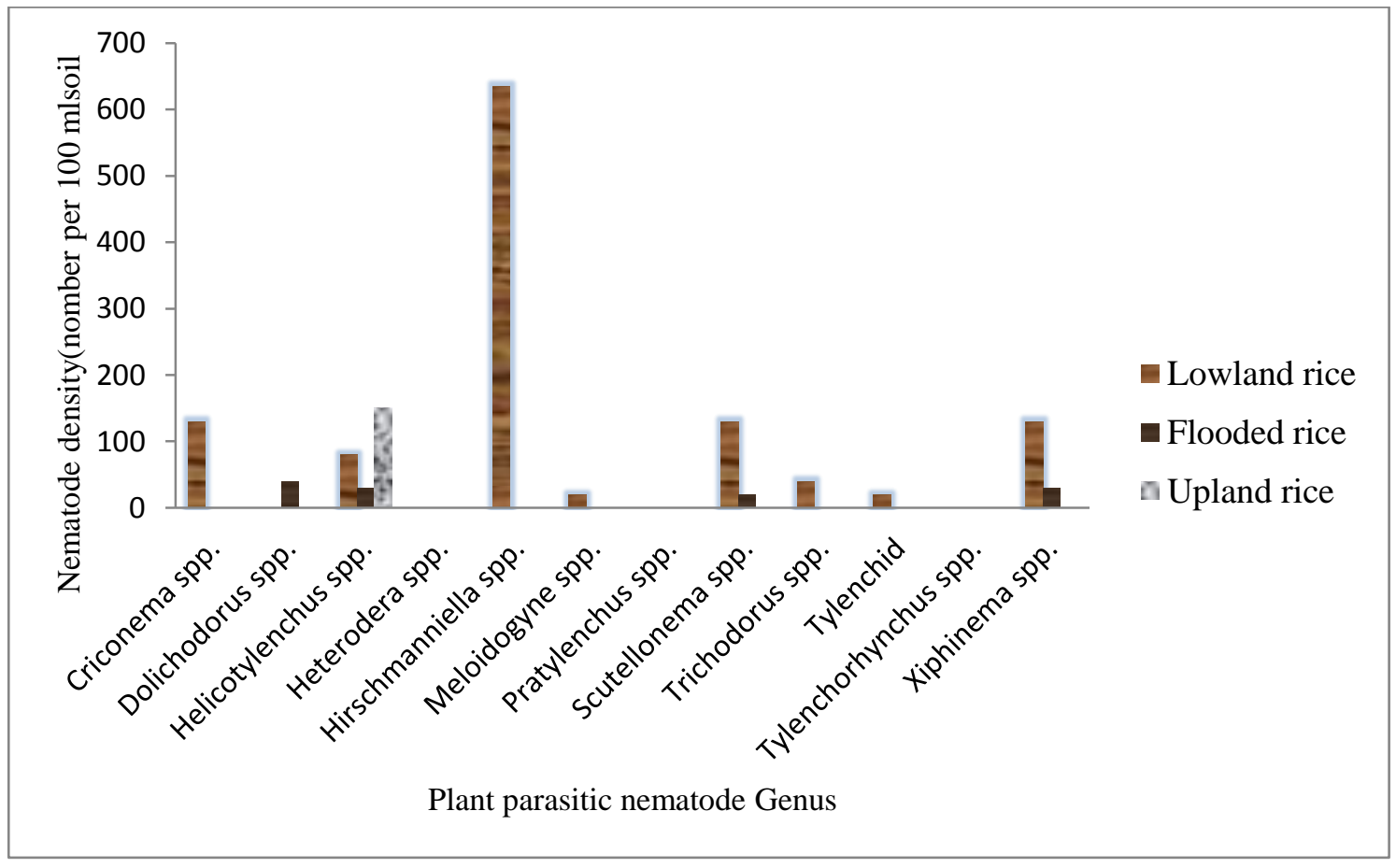

Figure 4: Mean population densities of nematodes in soil associated with flooded, lowland and upland rice ecosystems. 


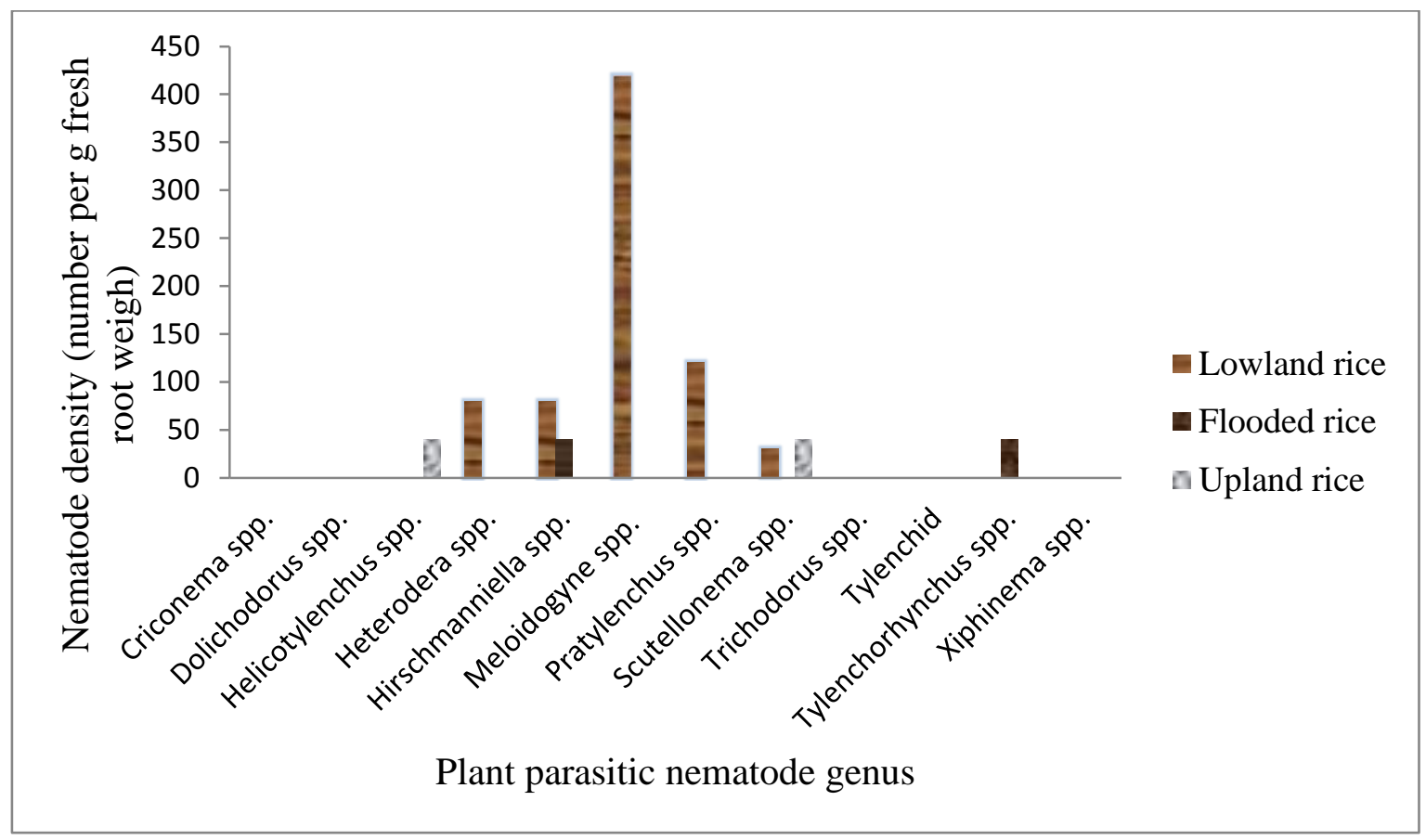

Figure 5: Mean population densities of nematodes in roots associated with flooded, lowland and upland rice ecosystems.

\section{DISCUSSION}

This study documented the occurrence, frequency and mean diversity of plant parasitic nematode genera associated with rice cultivation across agroecological zones of Togo targeting the major rice growing districts of the country. The results confirmed previous study from Coyne et al. (2000), who reported rice to be associated with plant parasitic nematodes in Togo. The inventory of parasitic nematodes associated with rice in Togo conducted in 1985 by Cadet and Mateille, cited by Coyne et al. (2000), showed that Meloidogyne, Scutellonema, Heterodera, Hirschmanniella, Pratylenchus and Helicotylenchus, were mainly observed to be associated with irrigated and strict rainfed rice production. Coyne et al. (2000) reported Hoplolaimus clarissimus and Peltamigratus nigeriensis to be associated with poor rice growth in Togo. The results of the current study have given a good indication of plant parasitic nematodes diversity on rice in different agroecological zones in Togo. Four of the twelve genera recorded Heterodera,
Meloidogyne, Pratylenchus and Xiphinema, are known to be among the 10 top plant parasitic nematodes of scientific and economic importance (Jones et al., 2013). As noted by several other authors (e.g., Coyne et al., 1998), the prevalence and mean intensity of nematode genera varied with agroecological zones. With 12 plant parasitic nematodes genera recorded across the different rice production sites sampled, the present research identified in addition 6 plant parasitic nematode genera, namely Criconema, Dolichodorus, Tylenchorhynchus, Trichodorus, Tylenchid and Xiphinema, as compared with the previous surveys (Coyne et al., 2000). The genera richness is quite significant compared to the 35 nematode genera known to parasitize rice worldwide (Bridge et al., 2005). Recorded taxa are numerically comparable to those described in the Philippine (Pascual et al., 2014), particularly for the genera Meloidogyne, Criconema, Hirschmanniella, Xiphinema Helicotylenchus, Pratylenchus and Tylenchorhynchus. The variability of nematode genera observed in this survey could 
be attributed to the increasing intensification of rice production in the country. Different factors could have contributed to the distribution of these nematodes in the agroecological zones, including production systems, cultural practices employed. The noticeable occurrence of additional plant parasitic nematodes in rice growing systems could be due to changes in agricultural practices, particularly in use of new rice varieties and the practice of rice intercropping with other crops, mainly vegetables, gown for fresh market. Indeed, with the increasing scarcity of water and rainfall, most growers are often shifting from monoculture rice system to intensive and continuous intercropping with several other crops among which are vegetables known to be hosts of plant parasitic nematodes (Sharma et al., 2006; Anwar et al., 2007; Singh and Khurma, 2007; Anwar et al., 2013), particularly in lowland ecosystem initially dedicated to rice cultivation. In Togo, rice is grown mostly in lowland ecosystem where continuous production without interruption may result in an increase in nematode population diversity and densities, as documented in this study. The practice of rice intercropping with other crops, coupled with the continuous growing of rice, may tend to favor the development and buildup of a higher population density of nematode communities in rice agroecosystems (Eche et al., 2013) as observed here for Helicotylenchus, Hirschmanniella, Meloidogyne and Scutellonema. Among these, Hirschmanniella was found to be the most prevalent and abundant genus, occurring in both root and soil samples. These results confirm those of several research studies on rice parasitic nematode communities. Indeed, several studies have noted the predominance of nematodes belonging to the genus Hirschmanniella known as the most frequent and most damaging to rice in lowland and irrigated ecologies (Coyne et al., 2000; Ravichandra et al., 2003; Bridge et al., 2005; Maung et al., 2010; Udo et al., 2011; Thio et al., 2017).

In both soil and root samples, the genus Meloidogyne was recorded in lowland ecosystem at high frequency and density. No individual was however observed in either upland or flooded ecosystem although Bridge et al. (2005) reported M. graminicola to be well adapted to flooded conditions. The result of the current research confirmed however results from other investigations indicating that rice roots under continuous flooding are free from $M$. graminicola, and population levels of the this species may not build up during the wet monsoon season (Win et al., 2013).

The genus Pratylenchus has been identified only in Zone 4 of Togo (forest zone), although it has been encountered in Ghana in both shallow and upland rice ecosystems (Coyne et al., 2000). This type of nematode identified also in Côte d'Ivoire, Nigeria, Senegal and The Gambia (Fortuner, 1975, cited in Pascual et al., 2014; Udo et al., 2011) seems to be favored by a rice monoculture (Win et al., 2013). Moreover, Pratylenchus is widespread throughout subSaharan Africa (Coyne et al., 2000) and known to be common in upland ecologies (Bridge et al., 2005; Pascual et al., 2014). S. bradys, the yam nematode, known to be a major causal agent of dry rot in West Africa (Coyne et al., 2006), was recorded from soil samples only in zone 2, the main yam growing zone in Togo, indicating the role of intercropping practices in dissemination of plant nematode species.

In contrary to what has often been reported about the prevalence of rainfed rice nematode (Namu et al., 2018), only 2 genera (Helicotylenchus and Scutellonema) have been recorded from upland ecosystem in the study. The low nematode prevalence in the upland ecosystem as observed in this survey could be explained by the rice variety which is mainly cultivated in this area in Togo. Indeed upland rice cultivation is mainly characterized by the accessions of African rice, O. glaberrima Steud. (Poales) (Gnamkoulamba, 2012), known to be resistant to plant parasitic nematodes (Plowright et al., 2002). In this ecosystem, contrary to previous work that reported Meloidogyne and Pratylenchus, recognized as ubiquitous in rainfed rice 
ecosystems (Pascual et al., 2014), the two genera were not observed during this research work probably because of the recognized resistant potential for $O$. glaberrima against nematodes (Soriano et al., 2000). With only two genera recorded in upland ecosystem our results contradicted that of Pascual et al. (2014), who reported in Philippines, higher parasitic nematode diversity in upland rice ecology with nine out the fourteen (14) recorded.

The genera Meloidogyne, Pratylenchus, and Hirschmanniella, were observed in both lowland and upland roots implying that they were root parasites of rice as was indicated in previous reports (Bridge et al., 2005; Triviño et al., 2016). This suggests that rice in Togo is a good host for these nematode genera. Our results showed higher nematode densities and diversities from soil than root samples, with Trichodorus spp., Tylenchid spp., Xiphinema spp., Criconema spp. and Dolichodorus spp., being recorded only from soil samples, usually at relatively low densities. Our findings confirmed the genus Criconema to be associated only to soil sample as reported by Bridge et al. (2005). Although Bridge et al. (2005) recorded nematode genera such as Tylenchorhynchus and Helicotylenchus in soil samples, usually at relatively low densities, and without any clear established association with rice, our results showed that Helicotylenchus was associated with both soil and root samples, while Tylenchorhynchus was recorded from rice root samples both at high densities. Pascual et al. (2014) in Philippines, reported Helicotylenchus, as well as Meloidogyne, Scutellonema and Hirschmanniella from both soil and rice root samples establish their association with rice production.

The genus Xiphinema, viruses vector nematode (Demangeat, 2007), was not found associated to rice cultivation in the previous studies conducted in Togo although it was reported to be associated to several important economic crops including vegetables, sorghum, cassava, yam, coffee and cotton (Coyne et al., 2000). Our result recorded however Xiphinema from rice growing plot with high frequent but low density. Such occurrence might result from rice being intercropped with other crops as indicated above.

The twelve plant-parasitic nematodes recorded in this survey have all been associated with yield reduction in many crops worldwide (Afolami et al., 2014). From these, rice pest statute of some nematode genera such as Meloidogyne, Hirschmanniella, Helicotylenchus, Tylenchorhynchus, Pratylenchus and Heterodera, is well established (Padgham et al., 2004; Pascual et al., 2014; Triviño et al., 2016). Tylenchorhynchus is common to rice grown in all rice ecologies (Bridge et al., 2005), while Heterodera is mainly an important parasite of strict and lowland rainfed rice (Bridge et al., 2005). Among recorded genera, Dolichodorus, Trichodorus, Tylenchid, Criconema, and Xiphinema, registered only in soil samples, do not appear to be subservient to rice roots and some of which may not be included in the list of nematodes known or suspected to cause yield loss in rice (Bridge et al., 2005).

\section{Conclusion}

The taxonomic list of plant parasitic nematodes established in the present study showed that rice is attacked by various plant parasitic nematodes in Togo. Species belonging to the genera Meloidogyne and Hirschmanniella are the most common, in particular because of their large numbers counted. It is evident that cropping systems and the intensification of rice production have played an important role in the diversity and density of plant parasitic nematodes in rice growing ecologies of Togo. This would explain the significant dynamics of nematode numbers noted in the lowlands compared to the two other rice cropping systems. The genus diversity of plant parasitic nematodes recorded in rice producing ecologies in Togo requires further investigations on their damage potential on rice crop performance to establish the economic threshold level and estimate a cost-benefit analysis on management practices. 


\section{COMPETING INTERESTS}

The authors declare that they have no competing interests.

\section{AUTHORS' CONTRIBUTIONS}

GA conducted the field research work, with the technical support of TM and AAKM and wrote the article. The contributions of TM and AAKM can be estimated at $20 \%$ each. TAK supervised the completion of the study, from the protocol to the writing of the manuscript. He helped GA in writing the article. His contribution is estimated at $60 \%$. The other authors contributed to the critical review of the article and their contribution can be estimated to $20 \%$.

\section{ACKNOWLEDGMENTS}

This study was funded by the West Africa Agricultural Productivity Program (WAAPP), in collaboration with the Université de Lomé-Togo. The authors thank Dr. ADOU Rahim Alimi for his support. We would like to thank the technicians of Laboratoire de Recherche sur les Agroressources et la Santé Environnementale (LARASE) for their collaboration and support in dada collection and processing data and Dr. Douro-Kpindou Okobi at IITA Benin Station for their critical review of the manuscript.

\section{REFERENCES}

Adjonou K, Djiwa O, Kombate Y, Kokutse AD, Kokou K. 2010. Etude de la dynamique spatiale et structure des forêts denses sèches reliques du Togo: implications pour une gestion durable des aires protégées. International Journal of Biological and Chemical Sciences, 4: 168-183.

http://dx.doi.org/10.4314/ijbcs.v4i1.5424 2

Afolami S, Solomon S, Daramola F. 2014. Biodiversity of plant-parasitic nematodes of Sugarcane in Bacita, Nigeria. Journal of Entomology and Nematology, 6: 7179. DOI:10.5897/JEN2014.0096

Anwar SA, Mahdi MM, McKenry MV, Qadir A. 2013. Survey of Plant-Parasitic Nematodes Associated With Four
Vegetable Crops Cultivated Within Tunnels. Pakistan Journal of Zoology, 45 : 595-603. 0030-9923/2013/0003$0595 \$ 8.00 / 0$

Anwar SA, Zia A, Hussain M, Kamran M. 2007. Host suitability of selected plants to Meloidogyne incognita in the Punjab. Pakistan. International Journal of Nematology, 17: 144-150.

Araya M, De Waele D, Vargas R. 2002. Occurrence and population densities of nematode parasite of bana (Musa AAA) root in Costa Rica. Nematropica, 32: 2133.

Bridge J, Plowright RA, Peng D. 2005. Nematode Parasite of Rice. In Plant Parasitic Nematodes in Subtropical and Tropical Agriculture, Luc M, Sikora RA, Bridge $\mathrm{J}$ (eds). $\mathrm{CAB}$ International: Wallingford, U.K; 87-130.

Correa PC, Schwanz da Silva F, Jaren C, Afonso Junior PC, Arana I. 2007. Physical and mechanical properties in rice processing. Journal of Food Engineering, 79: 137-142. https://doi.org/10.1016/j.jfoodeng.2006.0 1.037

Coyne DL, Hunt DJ, Plowright RA, Darboe MLK. 2000. Further observations on nematodes associated with rice in Côte d'Ivoire, The Gambia, Guinea and Togo. International Journal of Nematology, 2 : 123-130.

Coyne DL, Tchabi A, Baimey H, Labushagne N, Rotifa I. 2006. Distribution and prevalence of nematodes (Scutellonema bradys and Meloidogyne spp.) on marketed yam (Dioscorea spp.) in West Africa. Field Crops Research, 96: 142150. DOI 10.1016/j.fcr.2005.06.004

Coyne DL, Nicol JM, Claudius-Cole B. 2007. Practical Plant Nematology: A Field and Laboratory Guide. SP-IPM Secretariat, International Institute of Tropical Agriculture (IITA), Cotonou, Benin.

De Waele D, Elsen A. 2007. Challenges in Tropical Nematology. Annual Review Phytopathology, 45: 457-485. DOI 10.1146/annurev.phyto.45.062806.09443 8 
Decraemer W, Hunt DJ 2006. Structure and classification. In Plant nematology, Perry RN, Moens M (eds). CABI Publishing : Wallingford ; 3-32.

Demangeat G. 2007. Transmission des Nepovirus par les nématodes Longidoridae. Virologie, 11 : 309-21. DOI:10.1684/vir.2007.0102

Dourma M, Batawila K, Guelly KA, Bellefontaine R, Foucault BD, Akpagana K. 2012. La flore des forêts claires à Isoberlinia spp. en zone soudanienne au Togo. Acta Botanica Gallica, 159: 395409.

DSID. 2003. L'agriculture togolaise : caractéristiques, production et perspectives alimentaires. Lomé (Togo) ; $62 \mathrm{p}$.

DSID. 2016. Données statistiques sur les superficies, les rendements et les productions du maïs depuis la campagne agricole 1990-1991 à celle de 2015-2016; $75 \mathrm{p}$.

Eche NM, Iwuafor ENO, Amapui S, Bruns MAV. 2013. Effect of long-term soil management practices on nematode population in an Alfisol under continuous maize in Northern Guinea Savanna of Nigeria. International Journal of Agricultural Policy and Research, 1: 8086.

Gnamkoulamba A. 2012. Oryzae glaberrima Steud.: Usage et caractérisation agromormhologique. Mémoire de DEA Biologie de développement, Option: Biologie Végétale Appliquée. Université de Lomé ; 80p.

Hermann O. 2006. Nema-check : une nouvelle méthode d'analyse des nématodes. Le betteravier, 424.P 21.

Hooper DJ, Hallmann J, Subbotin SA. 2005. Methods for Extraction, Processing and Detection of Plant and Soil Nematodes. In Plant parasitic nematodes in subtropical and tropical agriculture, Luc M, Sikora RA, Bridge J (eds). CAB International: Wallingford, UK; 53-86.

Jones JT, Haegeman A, Danchin EGJ, Gaur HS, Helder J, Jones MGK, Kikuchi T, Manzanilla-López R, Palomares-Rius JE,
Wesemael WML, Perry RN. 2013. Top 10 plant-parasitic nematodes in molecular plant pathology. Molecular Plant Pathology, 14: 946-961. DOI: 10.1111/mpp. 12057

Ju-Kon K, Krishnan HB. 2002. Making Rice a perfect food: turning dreams into reality. Journal of Crop Production, 5: 93-130. https://doi.org/10.1300/J144v05n01_05

Keating BA, Carberry PS, Bindraban PS, Asseng S, Meinke H, Dixon J. 2010. Eco-efficient agriculture: concepts, challenges, and opportunities. Crop Sciences, 50: S-109-S-119. doi: 10.2135/cropsci2009.10.0594

Kokou K, Atato A, Bellefontaine R, Kokuste A, Caballé G. 2006. Diversité des forêts denses sèches du Togo (Afrique de l'Ouest). Revue D'Ecologie (la Terre et la Vie), 61: 225-246. http://hdl.handle.net/2042/55682

Maung ZTZ, Kyi PP, Myint YY, Lwin T, De Waele D. 2010. Occurrence of the rice root nematode Hirschmanniella oryzae on monsoon rice in Myanmar. Tropical Plant Pathology, 35: 003-010. DOI 10.1590/S1982-56762010000100001

Mendez del Villar P, Bauer JM. 2013. Le riz en Afrique de l'Ouest: dynamiques, politiques et perspectives. Cahier Agriculture, 22: 336-44.

Namu J, Karuri H, Alakonya A, Nyaga J, Njeri E. 2018. Distribution of parasitic nematodes in Kenyan rice fields and their relation to edaphic factors, rainfall and temperature. Tropical Plant Pathology, 43: $\quad 128-137 . \quad$ DOI: https://doi.org/10.1007/s40858-0170194-9

Navia D, Delgado A, Viera W, Báez F, Trevor J. 2017. Application of Bio-Products in Ecuadorian Agriculture: Case Banana. International Journal of Clinical and Biological Sciences, 2 (2): S7.

Nicol JM. 2002. Important nematode pests. In Bread wheat improvement and production, Curtis BC, Rajaram S, Gómez M (eds). FAO Plant Production and Protection Series; 567. 
Nicol JM, Turner SJ, Coyne DL, den Nijs L, Hockland S, Tahna Maafi Z. 2011. Current nematode threats to world agriculture. In Genomics and Molecular Genetics of Plant-Nematode Interactions, Jones J, Gheysen G, Fenoll C (Eds). Springer: Heidelberg, Germany; 21-43. DOI: https://dx.doi.org/10.1007/978-94007-0434-3_2

Onkendi EM, Kariuki GM, Marais $M$ and Moleleki LN. 2014. The threat of rootknot nematodes (Meloidogyne spp.) in Africa: a review. Plant Pathology, 63: 727-737. DOI:

10.1111/ppa.12202

Orisajo SB, Fademi OA. 2012. Plant-parasitic nematodes associated with coffee in Nigeria. International Journal of Science and Nature, 3: 768-772.

Padgham JL, Duxbury JM, Mazid AM, Abawl GS, Hossain M. 2004. Yield Losses by Meloidogyne graminicola on lowland rainfed rice in Bangladesh. Journal of Nematology, 36: 42-48.

Pascual MLD, Decraemer W, De Ley IT, Vierstraete A, Steel H, Bert W. 2014. Prevalence and characterization of plantparasitic nematodes in lowland and upland rice agro-ecosystems in Luzon, Philippines. Nematropica, 44:166-180.

Plowright RA, Caubel G, Mizen KA. 2002. Ditylenchus species. In Plant resistance to parasitic nematode, Starr JL, Cook R, Bridge J (eds). CABI Publishing: New York; 107-139.

Ravichandra NG, Krishnappa K, Reddy BMR. 2003. Occurrence and distribution of phytoparasitic nematodes associated with rice in Mandya District, Karnataka. Indian Journal of Nematology, 33: 178.

Sharma A, Haseeb A, Abuzar S 2006. Screening of field pea (Pisum sativum) selections for their reactions to root-knot nematode (Meloidogyne incognita). Journal of Zhejiang University Sciences B, 7: 209-214. DOI:10.1631/jzus.2006. B0209

Siddiqi MR. 2000. Tylenchida Parasites of Plants and Insects. CABI Publishing: Wallingford, UK; $833 \mathrm{p}$.
Sikora RA, Fernández E. 2005. Nematode parasites of vegetables. In Plant Parasitic Nematodes in Subtropical and Tropical Agriculture (2nd edn), Luc M, Sikora RA, Bridge J (eds). CABI Publishing: Wallingford; 319-392.

Singh SK and Khurma UR. 2007. Susceptibility of six tomato cultivars to the root-knot nematode, Meloidogyne incognita. The South Pacific Journal of Natural Science, 13: 73-77. DOI 10.1071/SP07013

Soriano IR, Prot JC, Matías DM. 2000. Expression of tolerance for Meloidogyne graminicola in rice cultivars as affected by soil type and flooding. Journal of Nematology, 32: 309-317.

Thio B, Ouedraogo LS, Sanon E, Sankara P and Kiemde S. 2017. Les nématodes parasites associés au riz dans les trois (3) principales écologies rizicoles au Burkina Faso. International Journal of Biological and Chemical Sciences, 11: 1178-1189. DOI: https://dx.doi.org/10.4314/ijbcs.v11i3.20

Triviño C, Navia-Santillán D, Velasco L. 2016. Plant-parasitic nematodes associated with rice in Ecuador. Nematropica, 46: 45-53.

Udo IO, Nneke NE, Uyioata AM. 2011. Survey of plant parasitic nematodes associated with rice (Oryza sativa L.) in South Eastern Nigeria. African Journal of Plant Science, 5: 617-619.

Win PP, Kyi PP, Maung ZTZ, De Waele D. 2013. Population dynamics of Meloidogyne graminicola and Hirschmanniella oryzae in a double ricecropping sequence in the lowlands of Myanmar. Nematology, 15: 795-807. DOI: $\quad$ http://dx.doi.org/10.1163/1568541100002719

World Bank. 2008. World Development Report 2008: Agriculture for Development. The World Bank, Washington D. 